\title{
KRITIK SOSIAL DALAM NASKAH DRAMA TIK, KARANGAN BUDI YASIN MISBACH: SUATU PENDEKATAN HERMENEUTIK
}

\author{
Catur Tri Mulyaningsih \\ SMP Al-Chalidiyah \\ E-mail: caturtriasih@gmail.com
}

\begin{abstract}
ABSTRAK
Penelitian ini bertujuan untuk mengetahui kritik sosial dalam naskah drama Tik, karangan budi Yasin Misbach. Penelitian menggunakan metode deskriptif kualitatif, analisis teks. Penelitian ini merupakan studi kepustakaan dan menggunakan naskah drama Tik, karangan Budi Yasin Misbach sebagai objek penelitian. Analisis dilakukan berdasarkan kajian sosiologi sastra dengan teori kritik sosial yang ditafsirkan menggunakan pendekatan hermeneutik Hans George Gadamer. Teori kritik sosial pada penelitian ini diklasifikasikan menjadi tiga aspek, yakni aspek ekonomi, politik, dan sosial budaya. Hasil penelitian menunjukkan kritik sosial pada aspek politik lebih dominan dibandingkan kritik sosial pada aspek sosial budaya dan ekonomi. Kecenderungan aspek politik ini dapat terjadi karena sebagian besar dialog yang terdapat dalam naskah Tik, membahas mengenai sindiran terhadap ketidakselarasan antara pemegang kekuasaan dan rakyat biasa. Analisis terhadap teks drama tersebut yakni menelaah unsur kritik sosial yang merupakan bagian dari unsur ekstrinsik dalam pembelajaran sastra.
\end{abstract}

Kata kunci: kritik sosial, drama, Tik, , hermeneutik

\section{SOCIAL CRITICISM IN TIK, BY BUDI YASIN MISBACH: A HERMENEUTIC APPROACH}

\begin{abstract}
Research aims to understand social criticism in a manuscript drama Tik, of Budi Yasin Misbach. The research using qualitative descriptive method, text analysis. The research is literature study and use of drama Tik, of Budi Yasin Misbach as an object research. The study is based on sociology literary criticism social with the theory interpreted used the Hans George Gadamer hermeneutic. The theory of social criticism on this research classified into three aspects, namely the economic aspect, political, and socio-cultural. The results of this analysis it can be concluded that the social criticism most dominating in a manuscript Tik, like criticism on the political social. The results of this study indicate that the social criticism of the political is more dominant than the social criticism of the socio-cultural and economics in the main character. The political aspects this could happen because most dialogue is in a manuscript Tik, discusses insinuations


against not aligned between successors and civilians. The analysis of the text of the drama are exploring social element of the criticism that is part of the extrinsic element in literary learning.

Keywords: social criticism, drama, Tik, , hermeneutic

\section{PENDAHULUAN}

Sastra merupakan media untuk menuangkan ide, gagasan, pemikiran dan perasaan penulis yang disajikan dalam sebuah karya, baik berupa sastra lisan maupun tulis. Dalam karya sastra, gagasan dan ide dituangkan dengan memadukan realita kehidupan yang terjadi dengan dunia imajinasi. Dengan demikian, sastra tidak sepenuhnya lahir dari dunia imajinasi ataupun dunia nyata saja, melainkan perpaduan antara kedua hal tersebut. Dengan memadukan antara daya imajinasi dan realita akan memudahkan pembaca untuk memahami peristiwa yang terjadi dalam suatu karya sastra karena pembaca masih bisa mengaitkan isi karya sastra tersebut dengan konsep realita yang ada dalam bayangan mereka.

Dalam menuangkan daya imajinasi dan realita ke dalam sebuah karya sastra, terlebih dahulu pengarang memahami genre apa yang akan ia pilih untuk karya sastranya. Salah satu contoh genre sastra ialah drama. Berbeda dengan prosa yang menggambarkan suatu peristiwa dalam cerita menggunakan kalimat tak langsung, isi cerita dan peristiwa pada drama dijelaskan langsung pada dialog-dialog yang terdapat dalam drama. Dialog-dialog tersebut membentuk suatu cerita dan ditulis dalam bentuk naskah drama (Satoto, 2012). Penulis naskah drama menggunakan dialog sebagai alat untuk mengintegrasikan latar belakang untuk memahami tokoh-tokohnya. Melalui dialog-dialog yang disajikan oleh pengarang, biasanya tercermin mengenai karakter 
tokoh, asal tokoh, dan status sosial tokoh dalam cerita, sehingga pembaca atau penikmat sastra dapat menafsirkan situasi yang terjadi dalam drama.

Sebelum dipentaskan, terlebih dahulu para pegiat teater, termasuk di dalamnya sutradara dan para aktor menafsirkan dan mengkaji sebuah naskah drama agar memiliki kesamaan paham untuk selanjutnya secara bersama-sama menvisualkan cerita yang terdapat dalam sebuah naskah drama (Waluyo, 2002). Jadi, antara para pemain drama dan penikmat sastra nantinya akan memiliki pandangan yang sama terhadap isi cerita yang disajikan dalam sebuah pementasan drama di atas panggung.

Tik, memberi gambaran tentang mudahnya permainan hukum yang ada di negeri ini. Petugas yang memiliki kuasa, menganggap remeh hal-hal yang sebenarnya penting, misalnya mengenai surat laporan kehilangan yang mengalami kesalahan pengetikan. Seseorang yang berkuasa akan bertindak sekehendak hatinya tanpa melihat sisi keadilan sebenarnya. Naskah yang ditulis oleh Budi Yasin Misbach ini menampilkan banyak sentilan mengenai kemiskinan, dan carut-marut ibukota yang lebih memandang seseorang berdasarkan penampilan luarnya saja. Melalui dialog-dialog yang terdapat dalam naskah, Budi Yasin Misbach menampilkan sindiran-sindiran tentang permasalahan yang sering terjadi di negeri ini, seperti kemiskinan, permainan politik kalangan atas, dan masyarakat yang memarginalkan kelompok masyarakat rendah.

Naskah drama Tik, merupakan salah satu hasil karya sastra yang lahir dari di tengah-tengah keadaan sosial masyarakat. Karya sastra tersebut sangat dekat dengan permasalahan dan gejolak sosial yang terjadi, baik antara pemerintah dengan masyarakat maupun antar sesama masyarakat. Permasalahan-permasalahan inilah yang sering dijadikan sebagai latar belakang terbentuknya suatu karya sastra (Pratiwi \& 
Siswiyanti, 2014). Oleh karena itu, karya sastra bisa dikatakan sebagai refleksi dari realita sosial yang terjadi di tengah-tengah kehidupan bermasyarakat.

Naskah drama ini merupakan karya sastra yang menampilkan cerminan kehidupan manusia sehari-hari, terutama dalam bermasyarakat. Pengarang sebagai salah satu bagian dari masyarakat turut merasakan gejolak dan permasalahan-permasalahan yang terjadi dalam masyarakat (Sumaryono, 1993). Melalui kepekaan yang tinggi, pengarang memasukkan keresahan-keresahan yang dirasakan di tengah permasalahan yang terjadi di sekitarnya dengan memunculkan kritikan dan sindiran-sindiran terhadap sesuatu yang dinilai tidak sesuai dengan aturan yang berlaku. Kritikan dan sindiran ini merupakan sebuah kritik sosial. Kritik sosial terjadi karena adanya kepincangan atau ketidakseimbangan situasi sosial di dalam lingkungan sosiokultural. Kritik sosial dapat disampaikan secara langsung maupun tidak langsung. Demonstrasi atau unjuk rasa merupakan salah satu bentuk contoh kritik sosial secara langsung, sedangkan contoh kritik sosial tidak langsung yaitu melalui media. Karya sastra berupa naskah drama merupakan salah satu media untuk menyampaikan kritik sosial tidak langsung. Kritik sosial ini diharapkan mampu menyadarkan pembaca dan masyarakat akan ketidakadilan dan penyimpangan nilai yang telah terjadi dan membuat perubahan akan permasalahan tersebut. Kebenaran sebuah bahasa tidak hanya terletak pada susunan gramatikal, melainkan pada tata pikir, intensi, dan implikasi dari sebuah ucapan (Mulyono, 2012).

Dalam meneliti kritik sosial pada sebuah karya sastra, terutama naskah drama, perlu adanya penafsiran atas simbol-simbol bahasa yang terdapat dalam teks. Penafsiran ini bukan hanya sekadar melihat teks dari makna harfiah, melainkan harus diteliti pula ke dalam makna yang tersembunyi dalam teks. Hal ini dikarenakan biasanya pengarang memiliki tujuan dan maksud yang dimasukkan ke dalam karya sastranya secara tersirat 
maupun tersurat. Oleh karena itu, dalam penelitian ini diperlukan pendekatan hermeneutika yang mengkaji sebuah karya sastra melalui sebuah interpretasi dan penafsiran terhadap teks berdasarkan simbol-simbol bahasa yang dituangkan pengarang dalam karya sastranya. Penelitian ini menggunakan pendekatan hermeneutika Hans George Gadamer. Hal ini dikarenakan hermeneutika Gadamer memberi kesempatan pembaca dan peneliti untuk menginterpretasi dan memahami dengan tidak terpaku pada mekanis, melainkan dengan membuka pikiran terhadap sesuatu 'yang lain' dalam teks (Mulyono, 2012).

Melalui sebuah penelitian mengenai kritik sosial yang terdapat dalam naskah drama Tik, karangan Budi Yasin Misbach, diharapkan dapat menggambarkan sebuah kritik sosial yang terdapat dalam sebuah naskah drama. Penelitian ini juga diharapkan dapat menjadi bahan referensi pembelajaran sastra di sekolah agar kegiatan belajar mengajar sastra tidak bersifat monoton. Selain itu, penelitian ini juga diharapkan dapat menambah khazanah penelitian sastra.

\section{METODE}

Lingkup penelitian dalam penelitian ini merupakan penelitian pustaka dengan sumber naskah drama Tik, karangan Budi Yasin Misbach yang terdapat dalam buku Antologi Bengkel Penulisan Naskah Drama yang diterbitkan pada tahun 2013 oleh Dewan Kesenian Jakarta. Naskah drama Tik, merupakan urutan ketiga dari dua belas naskah drama yang terdapat dalam buku tersebut yang dimulai dari halaman 54 sampai dengan halaman 92. Terdapat 39 halaman dalam naskah drama Tik,. Drama ini merupakan drama satu babak.

Metode penelitian yang digunakan ialah metode deskriptif kualitatif dengan pendekatan hermeneutika. Metode deskriptif kualitatif adalah metode yang memberikan 
gambaran data faktual yang ada dalam karya sastra untuk menjadi bahan analisis penelitian. Analisis hermeneutika adalah teknik anilisis yang digunakan untuk menafsirkan makna dalam teks secara tersirat dengan mengaitkan simbol bahasa yang terdapat dalam teks dengan berbagai peristiwa, seperti: peristiwa kebahasaan, seni, budaya, dan sejarah.

\section{HASIL DAN PEMBAHASAN}

Kritik sosial pada aspek ekonomi, politik, dan sosial budaya dalam naskah dapat dilihat dari naskah drama tersebut yang diperlihatkan dalam petunjuk teknis dan dialog pada naskah drama. Oleh karena itu, untuk meneliti bentuk kritik sosial dalam naskah drama Tik, dilakukan kajian hermeneutika teori Hans George Gadamer pada naskah.

Pada prinsipnya, hermeneutika selalu berkaitan dengan bahasa. Kata-kata sebagai satuan terkecil dalam hierarki suatu bahasa merupakan penanda-penanda yang diberikan pada realitas yang berupa penafsiran. Bahasa selalu melibatkan penafsiran kehendak batin, maka tidaklah semua yang diucapkan berhasil mempresentasikan seluruh isi hati, pikiran, dan benak seseorang. Menurut Hans George Gadamer, hermeneutika dalam karya sastra terdiri atas makna harfiah atau makna luaran dan makna substansial atau makna dalam. Makna tersebut digali melalui sebuah teks yang terdapat dalam naskah drama Tik,

Kritik sosial merupakan sebuah bentuk kepekaan pengarang terhadap gejalagejala sosial yang terjadi di sekitar masyarakat. Bentuk kepekaan tersebut berupa sebuah sindiran dan kritikan yang disajikan dalam sebuah karya sastra. Hal ini seperti yang terdapat dalam naskah drama Tik, yang menampilkan kritik sosial dalam bentuk cerita yang ringan. Pada penelitian ini, terdapat tiga aspek kritik sosial yang 
diklasifikasikan oleh peneliti dalam naskah Tik, seperti: aspek ekonomi, aspek politik, dan aspek sosial budaya.

Kritik sosial pada aspek ekonomi membahas mengenai hal ini dipahami sebagai gejala ekonomi secara umum. Aspek ekonomi yang dibahas meliputi kritik mengenai kemiskinan dan keserakahan. Dalam naskah Tik, tampak sindiran mengenai kemiskinan yang diucapkan Wardana dalam proses penginterogasian yang dilakukan petugas terhadapnya.

\author{
PETUGAS SATU: \\ Saya tidak menjebak. Itu bukan teori dan cara saya dalam mengorek \\ keterangan. \\ Saya cuma mencoba menganalisa, apa motivasi anda, menjadi maling \\ televisi dan seolah-olah memiliki keinginan untuk ditangkap. Seperti \\ disengaja gitu loh!
} WARDANA:

Tapi yang Bapak analisa itu salah, saya ini maling. Maling televisi. Bukan semacam orang yang Bapak tuduhkan itu. Dan saya hanya seorang pemulung. Pemulung sejati. Sudah tujuh turunan silsilah keluarga saya itu pemulung. Gak pernah ada yang jadi orang politik, pejabat, anarkis, komunis,masinis, pesimis, apalagi teroris! Sumpah Pak, demi apapun juga saya berani. Saya cuma pemulung, gak lebih dari itu. Kalaupun saya jadi maling, cuma rasa simpati saja sama kawan-kawan sesama pemulung yang ingin menikmati bagaimana rasanya menonton tivi bersama. Dan saya juga kasihan melihat istri saya sering bengong sendiri di gubuk karena belum punya anak. Jadi dia iseng terus kalau malam hari. Sering melamun di pojokan kardus. Masa Bapak gak kasihan melihat ini semua? Bapak kan juga manusia yang memiliki hati nurani, meskipun Bapak seorang petugas, tapi setidak-tidaknya, Bapak punya rasa simpatilah sedikit terhadap keinginan kami. (Tik, hlm. 61-62)

Tokoh Wardana berusaha menjelaskan kepada petugas bahwa ia hanya seseorang yang memiliki penghasilan dari profesinya sebagai pemulung, tidak lebih dari itu. Wardana juga menjelaskan alasan ia mencuri, karena rasa setia kawan kepada teman-temannya yang tidak memiliki televisi tetapi ingin menonton televisi bersama. Selain itu, rasa kasihan terhadap istrinya yang sering melamun di gubuk mereka juga 
merupakan alasan mencuri televisi yang dikemukakan Wardana kepada petugas yang menginterogasinya.

Berdasarkan dialog Wardana di atas, terdapat frasa pemulung sejati yang berarti bahwa seseorang yang sudah lama berprofesi sebagai pemulung, yakni suatu pekerjaan dengan mencari dan memungut barang bekas seperti koran, botol plastik, maupun kaleng dan kemudian menjualnya kepada pengusaha yang akan mendaur ulang barang bekas tersebut menjadi barang layak pakai. Dalam dialog tersebut juga terdapat kata gubuk yang memiliki makna rumah kecil dan biasanya berbentuk kurang bagus, serta bersifat sementara.

Makna substansial dalam hermeneutika yang terdapat pada kutipan dialog di atas yakni mengenai kemiskinan yang digambarkan oleh sosok Wardana yang bercerita mengenai keadaan dirinya, teman-teman di sekitarnya dan istrinya. Pemulung sejati berarti seseorang yang telah lama berada pada garis kemiskinan. Desakan ekonomi dan kebutuhan yang semakin meningkat mendorong seseorang untuk melakukan berbagai pekerjaan, meskipun hal tersebut merupakan pekerjaan di tempat yang jauh dari kata bersih. Hal ini sekaligus menjadi bukti bahwa masih banyak rakyat di negeri ini yang kurang atau bahkan dapat dikatakan tidak sejahtera.

Kalimat "sudah tujuh turunan silsilah keluarga saya itu pemulung" yang diucapkan Wardana dalam dialog di atas memberi makna bahwa masih banyak rakyat yang telah lama terkungkung dalam keadaan miskin dan belum dapat keluar dari masalah tersebut. Indonesia yang dikenal sebagai negara dengan kekayaan alam yang melimpah ternyata berbanding terbalik dengan apa yang dialami oleh rakyatnya. Kalimat yang diucapkan Wardana di atas juga merupakan bukti bahwa lambannya pergerakan yang dilakukan oleh pemerintah dalam mengatasi masalah kemiskinan. 
Selain kritik sosial pada aspek ekonomi, adapula kritik sosial pada aspek politik merupakan bentuk sindiran atau kritikan mengenai dunia politik secara umum yang disampaikan pengarang ke dalam naskah. Aspek politik yang dibahas pada naskah Tik, meliputi jabatan, wewenang, kekuasaan, kenaikan pangkat, keadilan, dan sistem birokrasi. Dalam naskah Tik, tampak aspek politik mengenai kekuasaan yang diucapkan Petugas Satu dalam proses penginterogasian yang dilakukannya terhadap Wardana.

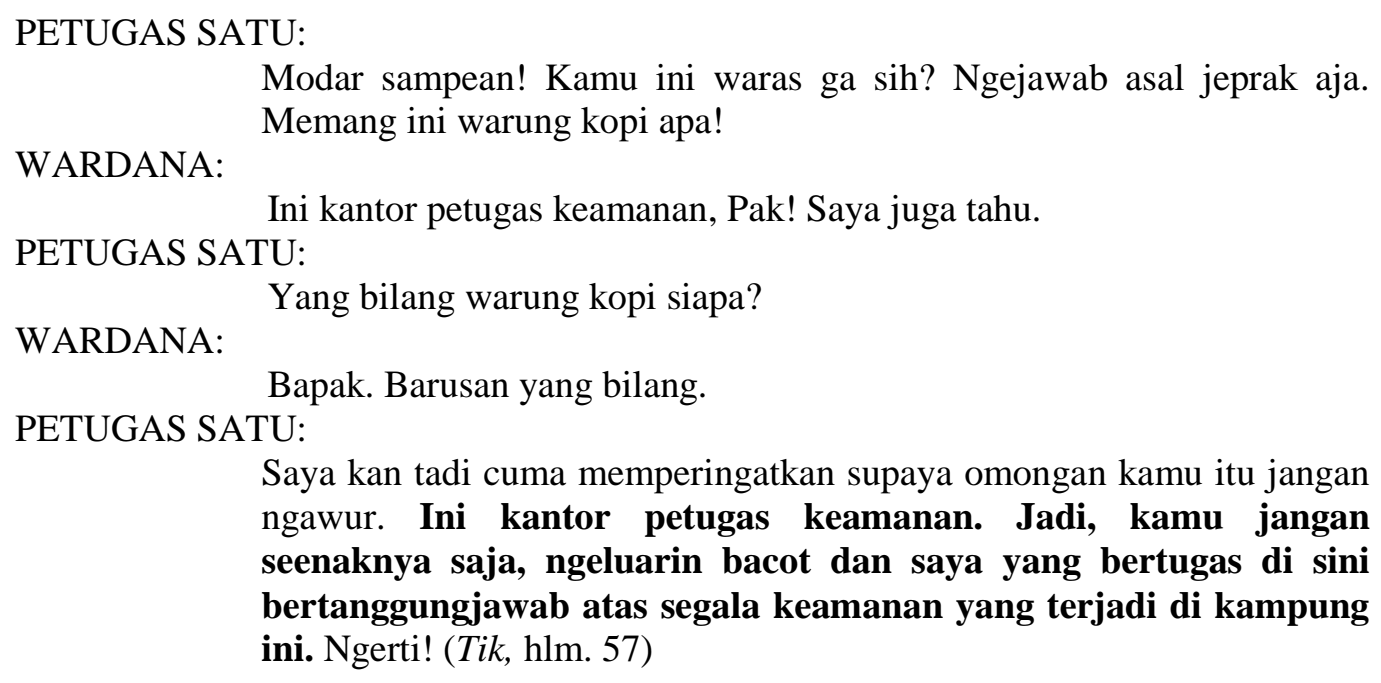

Saya kan tadi cuma memperingatkan supaya omongan kamu itu jangan ngawur. Ini kantor petugas keamanan. Jadi, kamu jangan seenaknya saja, ngeluarin bacot dan saya yang bertugas di sini bertanggungjawab atas segala keamanan yang terjadi di kampung ini. Ngerti! (Tik, hlm. 57)

Kutipan di atas menceritakan mengenai seorang petugas yang melarang Wardana selaku tersangka kasus pencurian untuk mengeluarkan pendapat secara berlebihan. Petugas tersebut merasa bertanggung jawab atas segala keamanan yang terjadi di wilayah tempat ia bertugas. Selain itu, petugas memperingatkan agar Wardana tidak sembarangan dalam berbicara di dalam kantor petugas.

Pada kutipan tersebut, terdapat kata bacot yang merupakan kata kasar bermakna harfiah mulut. Hal yang dimaksud dalam kalimat tersebut ialah ucapan atau ujaran yang diucapkan oleh Wardana. Selain itu, terdapat kata bertanggung jawab yang merupakan ungkapan bahwa seseorang yang menanggung segala sesuatunya. 
Dalam dialog yang diucapkan oleh Petugas Satu di atas, terlihat bahwa petugas menggunakan kekuasaannya dengan memakai kata "bertanggung jawab" untuk melarang Wardana mengeluarkan pendapatnya. Petugas menggunakan kekuasaannya sebagai alat untuk bertindak sewenang-wenang dengan tidak memberi kesempatan kepada tersangka kasus pencurian televisi untuk mengeluarkan pendapatnya. Hal tersebut menunjukkan jika seorang petugas dapat dengan mudah meminta seseorang untuk menuruti keinginannya.

Penggunaan kekuasaan yang tidak semestinya yang dilakukan oleh Petugas Satu tersebut menggambarkan telah menurunnya nilai politik yang terjadi di negeri ini. Kata "bacot” yang dikeluarkan oleh Petugas Satu juga mencerminkan seorang Petugas yang tidak menunjukkan pemimpin yang santun dalam berbicara. Dengan demikian, melalui sindiran yang terdapat dalam dialog tersebut, pengarang berusaha menunjukkan tingkat penurunan nilai politik saat ini dengan hilangnya jati diri seorang pemimpin yang sesungguhnya.

Kritik mengenai politik ini ditandai dengan adanya penyalahgunaan kekuasaan dan wewenang, ketidakadilan, korupsi, dan tidak berjalannya sistem birokrasi yang baik dan sesuai aturan. Seseorang yang memiliki tingkat jabatan yang tinggi memanfaatkan kekuasaannya untuk bersikap dan bertindak sewenang-wenang. Tindakan seperti itu membuat banyak rakyat yang menjadi korban kekejaman para pelaku politik. Selain itu, aspek politik mengenai korupsi yang tergambar dalam naskah Tik, bukan hanya dilakukan oleh para pemegang kekuasaan, melainkan rakyat kecil pun kini telah melakukan tindakan korupsi.

Terdapat pula kritik sosial pada aspek sosial budaya yang merupakan bentuk kritikan atau sindiran pengarang terhadap situasi dan gejala sosial yang menyinggung 
mengenai permasalahan kesenjangan sosial yang terjadi di dalam kehidupan masyarakat, pola pikir masyarakat, keadaan moral dan segala bentuk kritik yang berkenaan dengan kebiasaan suatu masyarakat yang bersifat negatif. Dalam naskah Tik, tampak aspek sosial budaya mengenai pola pikir masyarakat melalui dialog yang disampaikan oleh tokoh Wardana berikut.

PETUGAS SATU: WARDANA:

Kamu kan bisa nonton di rumah tetangga. Tanpa harus mencuri.

Tetangga saya, semuanya tidak punya, Pak. Dan saya mencuri, di samping untuk nonton bersama keluarga, juga bersama tetangga saya. Kasian mereka, mau nonton bola gak bisa, mau nonton sinetron juga gak bisa, mau nonton Indonesia mencari bakat gak bisa, masa harus nonton di kelurahan. Salah-salah bisa dicurigain, maklum orang seperti kami kerap dicurigai karena pakaiannya yang lusuh. (Tik, hlm. 56)

Pada kutipan di atas, terlihat Wardana sedang menjelaskan alasannya mencuri bahwa ia kasian terhadap orang-orang di sekelilingnya termasuk keluarga dan para tetangganya yang ingin menonton televisi bersama. Hal ini dilakukannya karena mereka tidak memiliki televisi. Selain itu, Wardana menjelaskan bahwa ia sering dicurigai karena pakaian lusuh yang ia kenakan. Oleh sebab itu, Wardana tidak memilih untuk menonton di kantor kelurahan. Berdasarkan kutipan dialog di atas, terdapat kata dicurigai yang merupakan suatu ungkapan untuk menunjukkan rasa curiga atau kurang percaya kepada seseorang. Sedangkan pakaian yang lusuh berarti pakaian yang kotor dan sudah usang serta memiliki warna yang telah pudar.

Makna substansial yang terkandung dalam kutipan di atas yakni mengenai pola pikir yang berkembang di masyarakat bahwa seseorang dinilai berdasarkan penampilan yang tampak oleh mata. Namun, sebenarnya yang terjadi adalah banyak orang-orang yang melakukan tindak kejahatan seperti penipuan dan tindak korupsi yang mengenakan pakaian bersih dan rapi layaknya manusia yang memiliki pribadi yang baik, padahal 
sebenarnya kejahatan yang dilakukannya telah merugikan banyak orang. Sebaliknya, seseorang yang dinilai buruk melalui penampilannya belum tentu memiliki pribadi yang buruk pula.

Dialog di atas merupakan sebuah bentuk kritik sosial terhadap pola pikir masyarakat yang sering menilai seseorang hanya melalui penampilan luar yang dikenakan. Hal ini menunjukkan pola pikir masyarakat yang telah tertanam kuat mengenai keadaan pemulung yang kotor, menjijikkan, dan cenderung melakukan halhal negatif karena memiliki tingkat pendidikan yang rendah. Pola pikir masyarakat yang seperti ini menandakan tergesernya nilai-nilai positif yang seharusnya terbentuk dalam pemikiran manusia bahwa setiap orang berhak dihargai dan dihormati sebagai makhluk sosial.

Berdasarkan penelitian yang telah dilakukan oleh peneliti, keseluruhan data yang diperoleh terdapat 30 data. Data menunjukkan, sebagian besar kritik sosial dalam naskah tersebut merupakan kritik pada aspek politik yaitu sebanyak 17 data atau sekitar $53 \%$, sedangkan aspek sosial budaya sebanyak 11 data atau sekitar 40\%, dan aspek ekonomi hanya sebanyak 2 data atau sekitar 7\%. Oleh sebab itu, dapat diketahui bahwa kritik sosial dalam naskah drama Tik, karangan Budi Yasin Misbach didominasi oleh kritik sosial pada aspek politik. Namun, kritik tersebut dilatarbelakangi oleh aspek ekonomi. Hal ini dikarenakan permasalahan-permasalahan yang terjadi pada bidang politik dipengaruhi oleh bidang ekonomi, seperti penyalahgunaan kekuasaan yang dilakukan oleh seseorang dengan jabatan tinggi yang merupakan masyarakat kelas atas dan bertindak sewenang-wenang terhadap pemulung sebagai masyarakat kelas bawah. Ini menunjukkan adanya keterkaitan antara aspek ekonomi yang membicarakan mengenai masyarakat kelas bawah yang memiliki tingkat perekonomian rendah dan 
masyarakat kelas atas dengan tingkat perekonomian tinggi, dan aspek politik yang membicarakan mengenai jabatan dan kekuasaan yang dimiliki oleh seorang pemimpin. Antara politik dan ekonomi saling terkait satu dengan yang lain. Kritik sosial pada aspek sosial budaya yang menempati posisi kedua menurut data penelitian setelah kritik pada aspek politik juga dipengaruhi oleh aspek ekonomi. Misalnya, pola pikir masyarakat terhadap pemulung sebagai masyarakat berekonomi rendah, dan perilaku buruk seperti mencuri yang dilakukan oleh seseorang yang tidak mampu membeli televisi. Hal-hal tersebut merupakan bukti adanya keterkaitan antara aspek ekonomi dengan aspek sosial budaya dan politik.

\section{KESIMPULAN}

Berdasarkan analisis yang telah dilakukan terhadap naskah drama Tik, karangan Budi Yasin Misbach, dapat diketahui bahwa bentuk kritik sosial pada naskah tersebut dapat dilihat melalui tiga aspek kritik, yaitu (1) aspek politik, (2) aspek sosial budaya, dan (3) aspek ekonomi. Ketiga aspek tersebut diperlihatkan melalui kata maupun kalimat yang terdapat di dalam dialog, baik secara tersirat maupun tersurat.

\section{UCAPAN TERIMA KASIH}

Ucapan terima kasih peneliti haturkan kepada berbagai pihak yang mendukung kelancaran pelaksanaan penelitian dan penulisan artikel ini. Dukungan ini memberikan peneliti motivasi untuk terus meneliti dan berkarya agar bermanfaat bagi ilmu pengetahuan. 


\section{DAFTAR PUSTAKA}

Pratiwi, Y. \& Siswiyanti, F. (2014). Teori drama dan pembelajarannya. Yogyakarta: Ombak.

Rais. (2017). Absurditas dalam naskah drama Jalan Lurus karangan Wisran Hadi dan implikasinya dalam pembelajaran sastra di SMA. 1(1). 44-62. doi: doi.org/10.21009/AKSIS.010103

Satoto, S. (2012). Analisis drama dan teater. Yogyakarta: Ombak.

Sumaryono, E. (1993). Hermeneutika sebuah metode filsafat. Yogyakarta: Kanisius.

Waluyo, H. J. (2002). Drama teori dan pengajarannya. Yogyakarta: Hanindita Graha Widya. 